\title{
Therapeutic strategies to reverse immunosuppressive breast cancer microenvironment
}

Deimante Tamkus $^{1 *}$ and Tejaswini Joginpally ${ }^{2}$

*Correspondence: tamkusde@msu.edu

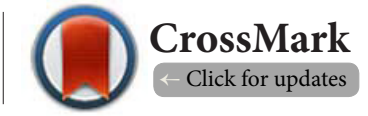

'Department of Hematology and Oncology, Michigan State University, USA.

2Department of Medicine, Michigan State University, USA.

\begin{abstract}
Breast cancer is one of the most commonly diagnosed cancers in women and is also the leading cause of death. Metastatic and recurrent breast cancer is associated with poor prognosis. Despite advanced multidisciplinary approaches in breast cancer treatment, there are still many therapeutic failures resulting in recurrence, metastasis, and death. Researchers have postulated that an appropriate microenvironment is needed for the growth of the tumor cells. As a result, there has been increased interest in developing innovative therapies targeting the microenvironment. Although chemotherapy is capable of inducing cytotoxic $\mathrm{T}$ cell infiltration within the tumor microenvironment, the efficacy of the antitumor immune responses may be limited by the development of immunosuppressive networks. Improved understanding of immune tumor promoting and antitumor mediators in breast cancer has created new opportunities for targeted therapies. Immunotherapy with immune checkpoint inhibitors is beginning to show promise for breast cancer. Adoptive $\mathrm{T}$ cell therapy remains an active research area in patients with breast cancer. This review summarizes the current knowledge of immune breast cancer microenvironment and outlines the innovative therapeutic regimens, including $\mathrm{T}$ cell based immunotherapy and combination regimens with immune checkpoint inhibitors, which are under clinical investigation.
\end{abstract}

Keywords: Tumor infiltrating lymphocytes, immunotherapy, breast cancer, biomarker

\section{Introduction}

The importance of an immune response to cancer has been known for decades. However, recent advances in immuno-oncology have greatly improved the understanding of the immune system and cancer interactions. Immunoediting refers to the process where the immune system can alter tumor progression [1]. It regulates both tumor quantity and quality. The process of cancer immunoediting has three distinct phases: elimination, equilibrium and escape phase. In the elimination phase, early transformed or dying tumor cells are recognized by the immune system and then eliminated. Eventually, continuous interactions between immune cells and tumor cells lead to the formation of tumor cells with acquired resistance against cytotoxic $T$ cells. The tumor cells with reduced immunogenicity then enter the equilibrium phase. In this phase, the interaction with the immune cells leads to the elimination of immunogenic tumor cells and emergence of resistant tumor cells under immune selection pressure [2]. The tumor cells that survived the elimination enter escape phase. The escape phase may occur at the tumor level or at the level of the tumor microenvironment. For example, at the tumor level the loss of major histocompatibility complex (MHC) class I protein that presents the antigens to tumor-specific $T$ cells can develop leading to reduced immunogenicity of tumor cells [3]. At the microenvironment level, the recruitment of regulatory T cells (Tregs) and myeloid derived suppressor cells (MDSCs) or expression of programmed death - 1 (PD-1)/ programmed death - ligand 1 (PD-L1) in immune infiltrates may lead to an immunosuppressive tumor microenvironment $[4,5]$. This paper will review potential therapeutic targets in the breast cancer microenvironment, including recent clinical data with immune checkpoint inhibitors and adoptive T cell therapy. Biological rationale for innovative combination regimens that are currently being investigated will be discussed.

\section{Review \\ Patterns of immune cell infiltration}

In an attempt to control malignant growth, tumor infiltrating lymphocytes (TILs) are recruited into the tumor. Patterns of 
Tamkus et al. Oncology Discovery 2016,

tumor associated leukocyte infiltration vary in different breast cancer subtypes. TILs Working Group 2014 has published guidelines describing the methodology to evaluate TILs in breast cancer [6]. TILs may be present either in the stromal or intratumoral compartment. Most clinical trials currently suggest that stromal TILs provide more clinically relevant information than intratumoral TILs. The working group consensus is that TILs should be assessed as a continuous parameter. Lymphocyte predominant breast cancer (LPBC) describes a tumor which contains more lymphocytes than tumor cells (thresholds vary between $50 \%$ and $60 \%$ of stromal lymphocytes). TILs are composed mostly of T lymphocytes (cytotoxic CD 8+ T cells and helper CD 4+T cells) and less commonly B lymphocytes. Comprehensive profiling of CD 4+ cells from invasive breast tumors has demonstrated $T$ cell subpopulations, including follicular T helper cells (Tfh), T helper 1 (Th1), T helper 2 (Th2), T17 effector memory cells and Tregs [7]. Unsupervised gene expression profiling of breast cancer associated stroma has revealed a gene signature predictive of good prognosis that was enriched for cytotoxic CD8+ T cell genes and natural killer cell activity [8]. While CD8+ cytotoxic T-cell infiltrates, NK cells, CD4+ Th1 cells, M1 macrophages, and dendritic cells are protective against tumor growth and are generally associated with better prognosis, there is a mounting evidence that $\mathrm{M} 2$ macrophages, CD4+ Th2 cells, MDSCs as well as inhibitory metabolites, such as adenosine, indoleamine 2,3-dioxygenase (IDO), promote tumor growth and are associated with worse outcomes [7,9-12]. Furthemore, $\gamma \delta T$ lymphocytes serve an important part in immune regulation [13]. Two major subsets of human $\gamma \delta T$ cells, V $\delta 1$ and V $\delta 2 T$ cells, have been identified. V $\delta 1 \mathrm{~T}$ cells are dominant at mucosal surfaces and in epithelial tissues. V $22 \mathrm{~T}$ cells are predominantly found in the peripheral blood and lymph nodes. In the peripheral circulation, $\gamma \delta \mathrm{T}$ cells comprise about 10 percent of the circulating T cells, but may expand to high levels during microbial infections. $\gamma \delta T$ lymphocytes produce large amounts of proinflammatory cytokines, such as interferon (IFN)- $\gamma$ and tumor necrosis factor (TNF)- $a$, and mediate anti-tumor cytotoxicity. Nonetheless, $\gamma \delta$ $T$ cells can promote tumor growth by IL-17 production. Tumor infiltrating $\gamma \delta T$ cells have been shown to be associated with poor survival in patients with breast cancer [14]. Recent study has identified a crosstalk between IL-17 producing $\gamma \delta$ T cells and GCSF dependent neutrophil expansion, leading to suppressed cytotoxic CD8+T cell responses and development of pulmonary and lymph node metastases [15].

\section{TILs serve as a robust prognostic biomarker}

Despite considerable heterogeneity of immune infiltrates, the evaluation of TILs in the tumor and stroma sections by hematoxylin and eosin stain have been shown to be associated with favorable prognosis in triple-negative breast cancer (TNBC) and human epidermal growth factor receptor 2 overexpressing breast cancer (HER2+BC). In a pivotal study, an independent positive association between TILs and complete pathological response (pCR) has been demonstrated [16] LPBC, defined as more than $60 \%$ of stromal or intratumoral lymphocytic infiltration, was associated with an exceptionally high rate of $\mathrm{PCR}(41.7 \%$ in LPBC tumors as compared to $12.8 \%$ non-LPBC tumors). In contrast, the $\mathrm{PCR}$ rate was only $2 \%$ in tumors without any TILs. A number of phase II randomized neoadjuvant trials confirmed an association between elevated stromal TIL levels and a high pCR rate $[17,18]$. The studies have demonstrated that TILs serve as a prognostic biomarker on a continuous scale as each $10 \%$ increment is associated with further increase in the rate of $\mathrm{pCR}$. In general, residual disease after neoadjuvant chemotherapy is associated with worse clinical outcomes. Interestingly, improved outcomes in patients showing higher TILs in the residual breast tumors after neoadjuvant chemotherapy have been demonstrated in a retrospective analysis [19]. In adjuvant setting, an increase of stromal tumor infiltrating lymphocytes (TILs) as continuously variable has been associated with favorable prognosis in TNBC and HER2+BC in 4 large randomized phase III studies [20-22]. With a median follow-up of 10.6 years, for every 10 $\%$ increase in stromal TILs, an $18 \%$ reduction of distant recurrence and $19 \%$ reduction risk of death were observed [21]. Currently the prognostic value of TILs was reported only in breast cancer treated with chemotherapy either in adjuvant or neoadjuvant settings. The significance of TILs for patients with breast cancer in the absence of chemotherapy is not yet defined.

\section{Emerging data on TILs as a predictive biomarker}

Data are emerging to support the role of TILs as a predictive biomarker to determine response to platinum chemotherapy in patients with TNBC. In the GeparSixto study, the $\mathrm{pCR}$ rates were approximately $15 \%$ higher with the addition of carboplatin to anthracyclines and taxanes [17]. Patients with TNBC who received carboplatin had a three-fold increased probability of pCR if the breast cancer had $60 \%$ or more of either intratumoral or stromal TILs (LPBC phenotype). In the study, $24.5 \%$ of patients had LPBC phenotype. In the multivariate analysis, the predictive effect of LPBC phenotype was shown to be robust and was able to predict a pCR in a similar range as hormone receptor status. The findings observed in the study may be attributed to platinum chemotherapy's ability to induce an immunogenic cell death [23]. The induction of immunogenic cell death leads to recruitment of dendritic cells to the tumor. The maturation of dendritic cells in the presence of platinum drugs downregulates PD-L1 and PD-L2 on immune cells and results in augmented T-cell response [24]. One possible explanation for LPBC sensitivity to platinum chemotherapy is that the presence of preexisting TILs in the tumors may be required for improved recognition and killing by activated T-cells. It is currently under investigation whether TILs expression impacts the disease-free survival in patients treated with platinum chemotherapy and the results of the study are awaited with interest. 
Tamkus et al. Oncology Discovery 2016,

While many studies have shown that TILs are a good prognostic factor in HER2 overexpressing breast cancer, TILs are not yet established as a predictive biomarker for HER2 targeted therapy. The FinHER trial evaluated an association between stromal TILs and trastuzumab response [22]. The study showed that each $10 \%$ increment in lymphocytic infiltrate was associated with an $18 \%$ reduction in the relative risk of distant recurrence in patients who received trastuzumab in addition to chemotherapy. Patients who had high TILs at diagnosis and did not receive trastuzumab had a worse outcome than those without TILs present. In contrast, a randomized phase III N9831 trial did not confirm predictive value of TILs when trastuzumab was added to standard antracycline, taxane chemotherapy [25]. 10-year Kaplan-Meier estimates for recurrence-free survival (RFS) in the chemotherapy alone arm were $90.9 \%$ and $64.5 \%$ for patients with high and low levels of stromal TILs. The 10-year estimates for RFS in the chemotherapy with trastuzumab arm were $80 \%$ and $80.1 \%$ for patients with high and low levels of TILs. In a multivariable analysis, stromal TIL status was significantly associated with outcome in chemotherapy alone arm but not in chemotherapy with trastuzumab arm. An exploratory analysis of NeoALTTO study evaluated TILs as a predictive biomarker in breast tumors treated in neoadjuvant setting with trastuzumab versus dual HER2 targeting strategy [26]. The study rationale was that the good prognostic group defined by high TIL levels may only require single agent trastuzumab with the chemotherapy instead of dual HER2 pathway inhibition. No significant interaction between TILs and treatment arm (dual HER2 targeting versus trastuzumab alone) and clinical outcomes was observed in this randomized phase III study. At this time TILs should not be used as a biomarker to either withhold or prescribe HER2 targeted therapy as suggested by TILs Working Group [6]. The inconsistent results of predictive TILs ability are limited by use of HER2 therapeutic agents with different mechanism on immune cells. Trastuzumab targets HER2-expressing tumor cells via antibody-dependent cellular cytotoxicity (ADCC) and its effect on immune cell infiltrate differs as compared to lapatinib, a tyrosine kinase inhibitor. Furthermore, the N9831 study suggests that treatment with trastuzumab is beneficial in patients with low TIL levels. Strikingly, trastuzumab adds no value in patients with high TIL levels. Ongoing investigations continue to evaluate components of immune infiltrates as predictors for trastuzumab efficacy in HER2+BC. A recent study reported that the HER2 enriched subtype showed a significant increase in immune index after treatment with trastuzumab but not after treatment with chemotherapy [27]. An increase of immune index after trastuzumab exposure but not at baseline was associated with higher complete pathological response rate. Evaluation of immune infiltrate identified CD4+ follicular helper T-cells as being associated with an improved response to trastuzumab. Furthermore, trastuzumab not only increased the immune index but also upregulated PD-L1 in HER2 enriched BC. The findings suggest that trastuzumab increases PD-L1 expression in the setting of a strong immune response. Based on the study results, the combination of trastuzumab and immune checkpoint inhibitors may be a reasonable approach, however, this hypothesis requires validation in large prospective studies.

\section{Reversion from M2-macrophage to M1-macrophage phenotype}

Several studies have demonstrated that in addition to T cells, immunosuppressive cells, such as tumor associated macrophages (TAMs) and MDSCs, also infiltrate tumor tissue. The tumor edge is a place where recruited immune and stromal cells interact with the tumor. It has been shown that increased TAMs are associated with increased vessel density and poor survival in patients with breast cancer $[28,29]$. Macrophage plasticity and heterogeneity are determined by response to specific stimuli, such as cancer cells or microbial molecules. Malignant tumor microenvironment transforms macrophage polarization from the $\mathrm{M} 1$ state that exhibits inflammatory and antitumorigenic properties to the $\mathrm{M} 2$ state that has proangiogenic and immune suppressive properties. The M1 macrophages express high levels of the MHC class I and II proteins that are required for the presentation of tumor specific antigens and play an important role in anti-tumor immunity. TAMs in a $\mathrm{M} 2$ macrophage state have a poor antigen presenting capability and suppress the immune response of $T$ cells. It has been shown that CSF-1 can polarize macrophages from an antigen-presenting $\mathrm{M} 1$ phenotype towards an immunosuppressive M2 state [27]. The potential of repolarization TAMs towards tumor cell killing phenotype by CSF-1 receptor (CSF-1R) targeting is an attractive strategy. Several CSF-1R inhibitors are in clinical development. Pexidartinib (PLX3397) is an oral CSF-1R inhibitor, which demonstrated an enhanced response rate, prolonged duration of response in patients with tenosynovial giant cell tumor, and was granted Breakthrough Therapy Designation by FDA in 2015. In the transgenic breast model, combined CSF-1R inhibition with paclitaxel demonstrated significant efficacy [28]. Furthermore, the reversion of $\mathrm{M} 2$ to $\mathrm{M} 1$ phenotype and enhanced infiltration of tumors by cytotoxic CD8+ T cells via CSF-1R targeting have been reported $[31,32]$. Ongoing clinical studies are evaluating the inhibition of the CSF-1 pathway with pexidartinib in combination with paclitaxel (NCT01042379), in combination with eribulin (NCT01596751), and in combination with pembrolizumab (NCT0245424) in breast cancer patients. Pexidartinib has also been selected for I-SPY 2 clinical trial: neoadjuvant and personalized adaptive novel agents to treat breast cancer (NCT01042379).

\section{Immune checkpoint pathway inhibition}

Tumor cells are able to suppress TILs infiltration through multiple mechanisms. Immune checkpoint pathways are inhibitory systems that play a paramount role for maintaining self-tolerance but also may allow immune escape of tumors. 
Tamkus et al. Oncology Discovery 2016,

Immune checkpoints participate in physiological processes, especially in the protection of tissues from damage when the immune system responds to infections. Checkpoint pathways are regulated by ligand/receptor interactions [33]. Programmed death-1 receptor (PD-1) and cytotoxic T-lymphocyte-associated antigen 4 (CTLA-4) are inhibitory molecules whose presence on lymphocytes supports a diminished immune response. PD-1 ligands, PD-L1 or PD-L2, are frequently expressed on tumor cells and can further minimize the immune response. An expression of PD-L1 on tumor cells interacts with PD-1 on CD8+ T cells and induces subsequent inactivation or exhaustion of T cells in the tumor microenvironment [34]. Results from clinical studies with PD-1 and PD-L1 inhibitors indicate promising clinical efficacy and a well tolerated toxicity profile in patients with advanced solid tumors. Durable responses due to the generation of antitumor memory have been demonstrated with this class of drugs [35]. The first immune checkpoint inhibitor ipilimumab was approved by the U.S. Food and Drug Administration (FDA) for the treatment of metastatic melanoma in March 2011. Since then, several other immune checkpoint inhibitors, including the CTLA-4 inhibitor tremelimumab and the PD-1 inhibitors nivolumab and pembrolizumab, have been FDA approved for the treatment of advanced solid tumors. Autoimmune toxicities associated with CTLA-4 antibodies are more common since the drug is not specific to antitumor T-cells and targets CTLA-4 on all T cells expressing the protein [36]. Inhibition of the PD-1/PD-L1 pathway is designed to reactivate TILs at the tumor site and results in less frequent and less severe autoimmune toxicity as compared to CTLA-4 inhibitors. Tumor response to cytotoxic chemotherapy is usually seen within weeks. When treating with immune checkpoint inhibitors, time to response can take several months. Pseudoprogression, defined as an increase in tumor size due to a large number of activated immune cells entering the tumor followed by tumor shrinkage, has been reported during treatment with immune checkpoint inhibitors. Thus, Response Evaluation Criteria in Solid Tumors (RECIST), designed to detect early effects of cytotoxic agents, may not provide an accurate assessment of immunotherapeutic agents [37]. Immune-related response criteria (irRC) have been developed [38]. Response evaluation by irRC is based on the total measurable tumor burden which incorporates measurements of index lesions and new lesions. In contrast to RECIST criteria, new lesions in the absence of rapid clinical deterioration do not define disease progression according to the irRC. Although response patterns observed with immunotherapy can be better captured with irRC, association of irRC with overall survival is yet to be defined.

The findings of early phase I studies with immune checkpoint inhibitors in patients with advanced breast cancer are promising. When tested as a single agent in patients with PD-L1 expressing heavily pretreated metastatic breast cancer, anti-PD-1 antibody (pembrolizumab) and anti-PD-L1 antibodies (atezolizumab, avelumab, durvalumab) demonstrated an overall response rate ranging from 4.8 to $24 \%$ by RECIST v1.1 criteria in four phase I studies [39-42]. The study design varied significantly in terms of patient population and PDL1 expression cut offs and different assays used. Despite the differences, durable responses were reported, especially in patients with TNBC. Several patients experienced pseudoprogression. In the JAVELIN study, treatment with avelumab produced $4.8 \%$ overall response rate in patients with all subtypes of breast tumors (unselected by PD-L1 expression) [41]. Response rates were slightly higher in TNBC as compared to HER2+BC and ER+BC ( $8.6 \%, 3.8 \%$ and $2.8 \%$ respectively). There was no difference seen in the response rate according to PD-L1 expression when $1 \%, 5 \%, 25 \%$ cut off points for PD-L1 expression were used in this study. Tumors with PD-L1 expression "hot spots" by immune cells within tumors seem to have higher response rates. In the KEYNOTE-028 study, the response rate in patients with metastatic ER+BC, PD-L1 expressing breast cancer, treated with pembrolizumab, has been reported at $12 \%$ ( $1 \%$ cut off for PD-L1 expression for stromal and/or tumoral TILs) [42]. Two early phase studies focused on evaluating the safety and efficacy of atezolizumab and pembrolizumab in PD-L1 expressing TNBC [39,40]. TNBC is considered to be a good candidate for immunotherapy because of a higher rate of somatic mutations and the production of neoantigens which can be recognized as foreign by the immune system. Also, TNBC is associated with higher TILs infiltration which can facilitate an immune response. The investigator assessed response rates by RECIST criteria ranged from $18.5 \%$ to $24 \%$ in patients with TNBC and PD-L1 expressing tumors. Furthermore, several patients achieved complete response and durable remissions lasting more than 10 months. The duration of response remains a meaningful clinical endpoint, especially in patients with TNBC. Overall, immune checkpoint inhibitors were safe and well tolerated. Grade 3 or higher treatment related toxicity ranged from $11 \%$ to $16 \%$. Most common side effects included fatigue, nausea, arthralgia, pyrexia, autoimmune hepatitis. Hypothyroidism, hyperthyroidism, adrenal insufficiency, autoimmune hepatitis, pneumonitis, thrombocytopenia were recorded as potentially immune-related treatment side effects.

\section{Combination of immunotherapy with conventional anticancer therapy}

It is unlikely that single agent immune checkpoint inhibitors will be sufficient for breast cancer treatment. The translation of immune therapy into the clinical practice will require a personalized approach along with a better understanding of the breast tumor immune landscape, including dynamic microenvironment changes induced by conventional anticancer therapies. Many tumors are poorly immunogenic which may occur due to insufficient antigen presentation to activate $T$ cells. Chemotherapy and radiotherapy are able to induce immunogenic tumor cell death that releases signals which induce a specific antitumor immune response. In addition, 
Tamkus et al. Oncology Discovery 2016,

chemotherapy may deplete immunosuppressive regulatory T cells, shift T cell phenotype from Th2 to Th1 and promote durable memory response through IFN secretion [43]. For example, low dose paclitaxel exhibits several immune regulating properties and may stimulate dendritic cell maturation, promote proinflammatory cytokine secretions and enhance the priming and lytic activity of cytotoxic $T$ cells $[44,45]$. The efficacy of monoclonal antibodies against HER2 is partially mediated through their ability to recruit immune cells and induce ADCC [46]. Although chemotherapy is capable of inducing cytotoxic $T$ cell infiltration within the tumor microenvironment, the efficacy of the antitumor immune responses may be limited by the development of immunosuppressive networks. To optimize the treatment response, strategies that include combining immunotherapy with conventional therapies, such as chemotherapy and radiation, are being evaluated in prospective clinical trials (Table 1). The immune modulating effects of radiation therapy have been reported by numerous investigators $[47,48]$. Several reports describe clinical responses outside radiation fields when treatment was combined with immunotherapy [49]. There has been a considerable effort to combine immunotherapy with stereotactic body radiation therapy which can be delivered in carefully selected areas while sparing normal tissue [50]. In addition, the complementary effects of radiation and immunotherapy may lead to durable systemic responses

Table 1. Clinical Trials of Combination Regimens with Immune Checkpoint Inhibitors in Breast Cancer.

\begin{tabular}{|c|c|c|c|c|}
\hline Intervention & $\begin{array}{l}\text { Study } \\
\text { Phase }\end{array}$ & Patient Population & $\begin{array}{l}\text { Estimated Study } \\
\text { Completion }\end{array}$ & $\begin{array}{l}\text { Clinical Trials.gov } \\
\text { Identifier }\end{array}$ \\
\hline \multicolumn{5}{|l|}{ Immunotherapy and chemotherapy } \\
\hline Nab-paclitaxel with or without Atezolizumab & III & metastatic $\mathrm{TNBC}^{\dagger}$ & May 2017 & NCT02425891 \\
\hline $\begin{array}{l}\text { Carboplatin and Nab-paclitaxel with or without } \\
\text { Atezolizumab }\end{array}$ & III & neoadjuvant TNBC & June 2022 & NCT02620280 \\
\hline Atezolizumab with Nab-paclitaxel & II & neoadjuvant TNBC & February 2021 & NCT02530489 \\
\hline Durvalumab with Paclitaxel and AC & $\mathrm{I} / \mathrm{II}$ & neoadjuvant TNBC & October 2019 & NCT02489448 \\
\hline Pembrolizumab with Eribulin & $\mathrm{Ib} / \mathrm{II}$ & metastatic TNBC & January 2018 & NCT02513472 \\
\hline $\begin{array}{l}\text { Pembrolizumab and Nab-paclitaxel with or without } \\
\text { Carboplatin followed by AC* }\end{array}$ & $\mathrm{Ib}$ & neoadjuvant TNBC & August 2017 & NCT02622074 \\
\hline \multicolumn{5}{|l|}{ Immunotherapy and radiotherapy } \\
\hline Pembrolizumab with Hypofractionated Radiotherapy & I & metastatic $\mathrm{BC}^{\ddagger}$ & February 2017 & NCT02303990 \\
\hline Pembrolizumab with Stereotactive Ablative Radiosurgery & I & oligometastatic BC & September 2020 & NCT02303366 \\
\hline $\begin{array}{l}\text { Durvalumab and Tremelimumab with Hypofractionated } \\
\text { Radiotherapy }\end{array}$ & I & metastatic BC & December 2018 & NCT02639026 \\
\hline Tremelimumab and brain irradiation & I & metastatic BC & September 2017 & NCT02563925 \\
\hline \multicolumn{5}{|l|}{ Immunotherapy and targeted therapy } \\
\hline Atezolizumab with T-DM1 or Trastuzumab, Pertuzumab & $\mathrm{Ib}$ & metastaticHER2+BC & August 2018 & NCT02605915 \\
\hline Pembrolizumab with Trastuzumab & $\mathrm{I} / \mathrm{II}$ & metastatic HER2+BC & December 2017 & NCT02129556 \\
\hline Durvalumab with Ibrutinib & $\mathrm{I} / \mathrm{II}$ & metastatic BC & June 2019 & NCT02403271 \\
\hline Durvalumab with Selumetinib & I & metastatic BC & April 2017 & NCT02586987 \\
\hline Durvalumab with Olaparib or Cediranib & $\mathrm{I} / \mathrm{II}$ & metastatic TNBC & December 2019 & NCT02484404 \\
\hline $\begin{array}{l}\text { Pembrolizumab with JAK inhibitor (INCB039110) or } \\
\text { PI3K-delta inhibitor (INCB050465) }\end{array}$ & I & metastatic TNBC & June 2017 & NCT02646748 \\
\hline Pembrolizumab with PLX3397 & $\mathrm{I} / \mathrm{II}$ & metastatic TNBC & July 2019 & NCT02452424 \\
\hline Pembrolizumab with Vorinostat and Tamoxifen & II & metastatic $\mathrm{ER}+\mathrm{BC}$ & August 2017 & NCT02395627 \\
\hline Nivolumab +/- Ipilimumab with Entinostat & I & metastatic HER2-BC ${ }^{\mathrm{II}}$ & January 2017 & NCT02453620 \\
\hline \multicolumn{5}{|l|}{ Combination immunotherapy } \\
\hline Nivolumab with Ipilimumab & $\mathrm{I} / \mathrm{II}$ & metastatic TNBC & December 2017 & NCT01928394 \\
\hline Durvalumab and Tremelimumab & II & metastatic HER2-BC & September 2017 & NCT02536794 \\
\hline Durvalumab and Epacadostat & $\mathrm{I} / \mathrm{II}$ & metastatic TNBC & March 2018 & NCT02318277 \\
\hline Pembrolizumab with Epacadostat & $\mathrm{I} / \mathrm{II}$ & metastatic TNBC & November 2017 & NCT02178722 \\
\hline Atezolizumab with Varlimumab & $\mathrm{I} / \mathrm{II}$ & metastatic TNBC & June 2019 & NCT02543645 \\
\hline Pembrolizumab and Enoblituzumab & I & metastatic TNBC & August 2020 & NCT02475213 \\
\hline
\end{tabular}

Abbreviations: ${ }^{*} \mathrm{AC}$ : doxorubicin, cyclophosphamide; ${ }^{\dagger} \mathrm{TNBC}$ : triple negative breast cancer; ${ }^{*} \mathrm{BC}$, breast cancer;

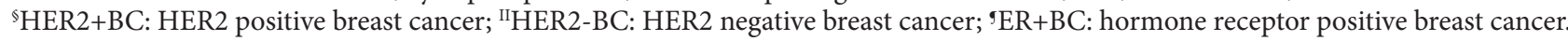


Tamkus et al. Oncology Discovery 2016,

http://www.hoajonline.com/journals/pdf/2052-6199-4-1.pdf

doi: $10.7243 / 2052-6199-4-1$

through immunological memory. Prospective clinical trials (NCT02303366, NCT02303990) are evaluating efficacy and safety of the combination treatment in patients with metastatic breast cancer.

Combination of immunotherapy with targeted therapy In solid tumors, targeted therapies have been shown to produce initial good responses but eventually resistance develops. On the contrary, immunotherapy has been able to produce durable responses in a minority of the patients. Due to non-overlapping toxicity and promising preclinical data, there have been substantial efforts to evaluate combination strategies in patients with breast cancer. Several trials are underway to investigate the safety and efficacy of combining targeted therapy (e.g., PARP, MEK, PI3K, JAK, BTK inhibitors) and immunotherapy (e.g, antibodies against CTLA-4, PD-1, PD-L1, OX40, and CD27) in patients with locally advanced or metastatic breast cancer (Table 1). Epigenetic alterations play a key role in the tumor progression and have been shown to associate with resistance to anticancer therapy. There are emerging data showing that epigenetic silencing of immune related genes may further enhance the immunosuppressive tumor microenvironment. Somatic mutations in epigenetic regulators are increasingly being identified. Preclinical studies suggest that $\mathrm{MHC} \mathrm{I-related} \mathrm{genes} \mathrm{are} \mathrm{downregulated} \mathrm{through}$ epigenetic silencing [51]. Recent data indicate that patients with tumors harboring those mutations may particularly benefit from epigenetic therapy, including hypomethylating agents and histone deacytelase (HDAC) inhibitors. To date, several drugs targeting epigenetic changes have achieved regulatory approval by FDA. The HDAC inhibitor, entinostat, has been granted a Breakthrough Therapy designation from FDA based on the randomized phase II, double-blind, placebocontrolled study results in patients with metastatic breast cancer [52]. A randomized phase III study for patients with $E R+B C$ is ongoing (NCT02115282). Recently there has been an interest to combine several immunotherapy approaches in combination with targeted agents. Increased immunotherapy efficacy has been observed in MHC-I positive tumors as compared to tumors with MHC-I low expression [53]. Lower MHC-I expression on tumor cells has developed as a mechanism to escape immune surveillance. There has been an interest to revert this aberration to optimize tumor cell recognition by immune system. Recent data imply that epigenetic therapy may serve as a "priming" tool before immunological therapies [54]. The combination of dual epigenetic drugs (with 5-azacytidine, a DNA methyltransferase inhibitor and entinostat, a HDAC inhibitor) and dual immune checkpoint inhibition (with anti-PD-1 and anti-CTLA-4 antibodies) was able to completely eradicate tumors in murine breast and colorectal models [55]. The potential use of epigenetic therapy in combination with immunotherapy is currently being explored in a prospective clinical trial in patients with metastatic HER2 negative breast cancer (NCT02453620) and hormone therapy resistant breast cancer (NCT02395627). These studies are expected to establish a toxicity profile and provide preliminary efficacy data of the combination.

\section{Adoptive T cell therapy}

Several adoptive T cell therapy approaches, consisting of collection, ex vivo expansion, and reinfusion of activated T cell lymphocytes to the patient, have been evaluated in patients with breast cancer. T cells are the most specific and potent cytotoxic cells of the immune system. $\gamma \delta T$ cells do not express CD4 or CD8 but express a T cell receptor (TCR) and natural killer cell receptor (NKR), such as NKG2D. Antigen recognition by $\gamma \delta T$ cells is dependent upon the particular variable region of the TCR and/or NKRs, and does not require MHC class I and II molecules for antigen recognition. This characteristic feature of $\gamma \delta$ T cells is an attractive tool for immunotherapy as tumors downregulate MHC molecules to evade immune surveillance. The safety and efficacy of $\gamma \delta$ T cell based immunotherapy have been evaluated in several clinical trials $[56,57]$. Peripheral blood cells expressing the $\mathrm{V}$ gamma $9 \mathrm{~V}$ delta 2 TCR (VY9V82 T cells) can be primed with synthetic phosphoantigens, expanded in vitro and then transferred in vivo. Another strategy is to stimulate $\mathrm{V} \gamma 9 \mathrm{~V} \delta 2 \mathrm{~T}$ cells in vivo by treating patients with bisphosphonates. Treatment with pamidronate or zoledronate enhances intracellular levels of isopentenyl pyrophosphate (IPP) by the inhibition of farnesyl diphosphate synthase and leads to the expansion of human Vy9V82 T cells [58]. In the clinical study, heavily pretreated breast cancer patients with bone metastases were treated with zoledronate for 3 months in combination with low-dose IL-2. The study goal was to investigate bisphosphonate treatment on circulating $\mathrm{V} \gamma 9 \mathrm{~V} \delta 2$ cell maturation and to evaluate clinical response to the treatment [56]. The results demonstrated that treatment with zoledronate polarized $\mathrm{V} Y 9 \mathrm{~V} \delta 2$ cells toward an IFNY-producing phenotype. Moreover, a significant correlation was detected between $\mathrm{V} \gamma 9 \mathrm{~V} \delta 2$ cell number and clinical outcomes. In the study, no complete response was seen, but partial response and stable disease were observed. Treatment was well tolerated with minimal side effects, such as transient flu-like symptoms and local erythema at IL-2 administration site. There has been some concern of using IL-2 to activate $\gamma \delta \mathrm{T}$ cells. In preclinical studies, IL-2 was able to induce T regs, which can inhibit $\gamma \delta T$ cell responses [59]. This observation highlights the need to investigate alternative approaches for $\gamma \delta \mathrm{T}$ cell activation. Another important $\gamma \delta \mathrm{T}$ cell function, which can be utilized for immunotherapy, is the upregulation of CD16 (FcyRIII receptor) by a subset of Vy9V $22 \mathrm{~T}$ cells and participation in antibody-mediated immune responses such as ADCC. There are substantial preclinical data showing a significant improvement in cytotoxicity of $\gamma \delta T$ cells when combined with specific antitumor antibodies such as trastuzumab, rituximab, alentuzumab $[\mathbf{6 0}, \mathbf{6 1}]$. In the HER2+BC mouse model, combination of trastuzumab and adoptively transferred $\gamma \delta$ T cells achieved a superior growth control as 
Tamkus et al. Oncology Discovery 2016,

compared with the single treatment modality approach [62].

To date, the efficacy of $\gamma \delta T$ cell immunotherapy has been limited due to $T$ cell exhaustion. Over the last decade, chimeric antigen receptor (CAR) - expressing $T$ cells have emerged as an attractive option for hematologic malignancies. Several advantages of adoptive CAR T-cell therapy include MHC independent target recognition, ability to cross the blood-brain barrier, and development of memory T cells, possibly leading to durable responses. However, unique side effects, such as cytokine release syndrome (CRS) and neurotoxicity, have been observed. CRS is a potentially life threatening toxicity, which occurs as a result of a cytokine storm (elevation of IL- 6 , IFN- $\gamma$, TNF- $\gamma$ levels) and may also be associated with macrophage activation syndrome/hematophagocytic lymphohistiocytosis [63]. Life threatening complications of CRS include cardiac and respiratory dysfunction, neurologic toxicity, renal, hepatic failure, and disseminated intravascular coagulation. Treatment with tocilizumab, anti-IL-6 antibody, with or without corticosteroids may reverse the syndrome. It has been shown that severity of CRS is greater in patients with higher disease burden and tumor lysis syndrome may also occur with CRS. Results of a phase I study evaluating anti-HER2Bi armed antiCD3 activated T cells in patients with metastatic breast cancer have been published [64]. Three weeks before the treatment, 23 patients underwent leukopheresis to obtain T cells. Treatment consisted of eight infusions of anti-HER2xanti-CD3 activated T cells administered twice weekly for consecutive 4 weeks in combination with low dose IL-2 and GM-CSF. Most common side effects were chills and headache. In the study, subdural hematoma occurred in one patient and one patient died due to congestive heart failure secondary to digoxin toxicity. Antitumor responses (one partial response, eleven patients with stable disease) were seen with durable responses lasting beyond 7 months. Increase in Th1 cytokines and IL12 levels were seen in patients with HER2-BC and HER2+BC. Infused activated $T$ cells were detected in the circulation for a week. However, an increase of endogenous cytotoxic T cells and cytokine response persisted for up to 4 months. This phase I dose study showed that the treatment of metastatic breast patients with HER2Bi-armed T cells was safe and well tolerated. Phase II study to evaluate efficacy and safety of neoadjuvant chemotherapy followed by HER2Bi armed anti-CD3 activated T cells is being conducted (NCT01147016). Several other trials, evaluating engineered $\mathrm{T}$ cells against breast tumor molecules, such as c-Met, mesothelin, are currently under way for patients with locally advanced and metastatic breast cancer (NCT01837602, NCT02414269).

Solid tumors do not have common tumor associated antigens as compared to hematologic malignancies, and efforts to develop effective CAR T cells for solid tumors have been less successful. Other limiting factors for successful CAR T therapy include inefficient homing of $T$ cells to the tumor and an immunosuppressive microenvironment effect on CAR T cell function. Strategies to overcome the immunosuppressive environment and to increase the CART antibody therapeutic efficacy with PD-1 blockade showed promising results in preclinical tumor models [65]. Innovative approaches to redirect $T$ cell to tumor cells has been developed by utilizing single-chain bispecific antibody constructs of the bispecific T-cell engager (BiTE) class. Highly potent and specific cell lysis occurs through the immunological synapse between $\mathrm{T}$ cells and tumor cells independent of peptide antigen presentation, TCR specificity, and co-stimulatory signals. In contrast to CAR T cells, BiTE antibodies engage endogenous T cells and avoid the need for ex vivo expansion and manipulation of T cells. BiTE antibodies such as blinatumomab with specificity for CD3 on T cells and for CD19 on leukemia cells have shown significant efficacy and have been approved by FDA for the treatment of patients with Philadelphia chromosome-negative relapsed or refractory B-cell precursor ALL. Short half-life of BiTE antibodies requires continuous infusion for 4-8 weeks but also may serve as an advantage to control drug levels. Side effects of BiTE antibodies, including CRS and neurotoxicity, may occur from polyclonal T cell activation and correlates with tumor burden and selected antigens. A series of BiTE antibodies for solid tumor treatment are being developed [66].

\section{Conclusions and future directions}

The clinical results to date indicate that targeting the immune suppressed tumor immune microenvironment will play an important role in the therapy of breast cancer. A large pool of new targeted agents for breast cancer treatment is entering clinical development and combination strategies are becoming increasingly complex. Combination regimens, incorporating immunotherapy agents, have a potential to overcome breast cancer resistance mechanisms, resulting in higher response rates and prolonged response durations. It cannot be overemphasized that long term observation with respect to risks of late toxicities will be necessary in these trials. Modified treatment response criteria such as irRC may be implemented in order to capture the specific response patterns seen with immunotherapeutic agents. The main challenge will be the development of companion diagnostics that will enable the selection of an appropriate patient population to maximize treatment efficacy. The challenge for future clinical trials is to design biomarker strategies that can predict the response to immunotherapy to maximize treatment efficacy. The presence of stromal TILs is related to improved outcome in triple-negative and HER2 overexpressing tumors and should be considered as a stratification factor in future clinical trials. Preferably, the impact of immunotherapy should be investigated in both the systemic circulation and tumor microenvironment. There is an ongoing debate which biomarker best predicts a response to immune checkpoint inhibitors in breast cancer [67]. In 2015, the FDA approved first companion diagnostic test, the PD-L1 IHC 22C3 pharmDx test, which can detect PD-L1 protein expression in non-small cell lung cancer, in conjunction with an immune checkpoint 
Tamkus et al. Oncology Discovery 2016,

http://www.hoajonline.com/journals/pdf/2052-6199-4-1.pdf

doi: $10.7243 / 2052-6199-4-1$

inhibitor pembrolizumab. Several studies demonstrated that other biomarkers may also be able to predict response rates to PD-L1 inhibitors. An increased burden of somatic mutations has positively correlated with a response to PD-1 inhibitors in non-small cell lung cancer and CTLA-4 inhibitor in melanoma $[68,69]$. Furthermore, high response rates to PD-1 blockade in patients with mismatch repair-deficient cancer have been demonstrated [70]. In breast cancer, a predictive biomarker for drugs targeting breast cancer microenvironment yet needs to be proven.

\section{List of abbreviations}

TIL: Tumor infiltrating lymphocyte

T reg: Regulatory T cell

MDSC: Myeloid derived suppressor cell

PD-1: Programmed death -1

PD-L1: programmed death - ligand 1

TNBC: Triple-negative breast cancer

HER2+BC: Human epidermal growth factor

receptor 2 overexpressing breast cancer

ER+BC: Estrogen receptor positive breast cancer

LPBC: Iymphocyte predominant breast cancer

pCR: Complete pathological response

ADCC: Antibody dependent cellular cytotoxicity

TAM: Tumor associated macrophage

CSF-1R: Colony stimulating factor-1 receptor

CTLA-4: Cytotoxic T-lymphocyte-associated protein 4

CART cell: Chimeric antigenic receptor T cell

BiTE: Biallelic T-cell engager

Competing interests

The authors declare that they have no competing interests.

\section{Authors' contributions}

\begin{tabular}{|l|c|c|}
\hline Authors' contributions & DT & TJ \\
\hline Research concept and design & $\checkmark$ & $\checkmark$ \\
\hline Collection and/or assembly of data & $\checkmark$ & $\checkmark$ \\
\hline Data analysis and interpretation & $\checkmark$ & $\checkmark$ \\
\hline Writing the article & $\checkmark$ & $\checkmark$ \\
\hline Critical revision of the article & $\checkmark$ & $\checkmark$ \\
\hline Final approval of article & $\checkmark$ & $\checkmark$ \\
\hline Statistical analysis & $\checkmark$ & $\checkmark$ \\
\hline
\end{tabular}

\section{Acknowledgement}

The authors thank Cheryl Leece for technical assistance.

\section{Publication history}

Editors: Jim Song, Penn State University College of Medicine, USA. Alfons Lawen, Monash University, Australia.

Received: 15-Apr-2016 Final Revised: 23-May-2016

Accepted: 30-May-2016 Published: 10-Jun-2016

\section{References}

1. Chow MT, Moller A and Smyth MJ. Inflammation and immune surveillance in cancer. Semin Cancer Biol. 2012; 22:23-32. | Article | PubMed

2. Chew V, Toh $\mathrm{HC}$ and Abastado JP. Immune microenvironment in tumor progression: characteristics and challenges for therapy. J Oncol. 2012; 2012:608406. | Article | PubMed Abstract | PubMed FullText

3. Seliger B. Different regulation of MHC class I antigen processing components in human tumors. J Immunotoxicol. 2008; 5:361-7. | Article PubMed
4. Labiano S, Palazon A and Melero I. Immune response regulation in the tumor microenvironment by hypoxia. Semin Oncol. 2015; 42:378-86. | Article | PubMed

5. Brown JA, Dorfman DM, Ma FR, Sullivan EL, Munoz O, Wood CR, Greenfield EA and Freeman GJ. Blockade of programmed death-1 ligands on dendritic cells enhances $T$ cell activation and cytokine production. $J$ Immunol. 2003; 170:1257-66. | Article I PubMed

6. Salgado R, Denkert C, Demaria S, Sirtaine N, Klauschen F, Pruneri G, Wienert S, Van den Eynden G, Baehner FL, Penault-Llorca F, Perez EA, Thompson EA, Symmans WF, Richardson AL and Brock J et al. The evaluation of tumor-infiltrating lymphocytes (TILs) in breast cancer: recommendations by an International TILs Working Group 2014. Ann Oncol. 2015; 26:259-71. | Article | PubMed

7. Gu-Trantien C, Loi S, Garaud S, Equeter C, Libin M, de Wind A, Ravoet M, Le Buanec H, Sibille C, Manfouo-Foutsop G, Veys I, Haibe-Kains B, Singhal SK, Michiels S, Rothe F, Salgado R and Duvillier H et al. CD4(+) follicular helper T cell infiltration predicts breast cancer survival. J Clin Invest. 2013; 123:2873-92. | Article I PubMed Abstract | PubMed FullText

8. Finak G, Bertos N, Pepin F, Sadekova S, Souleimanova M, Zhao H, Chen H, Omeroglu G, Meterissian S, Omeroglu A, Hallett M and Park M. Stromal gene expression predicts clinical outcome in breast cancer. Nat Med. 2008; 14:518-27. I Article I PubMed

9. Ali HR, Provenzano E, Dawson SJ, Blows FM, Liu B, Shah M, Earl HM Poole CJ, Hiller L, Dunn JA, Bowden SJ, Twelves C, Bartlett JM, Mahmoud SM, Rakha E, Ellis IO, Liu S, Gao D, Nielsen TO, Pharoah PD and Caldas C. Association between CD8+ T-cell infiltration and breast cancer survival in 12,439 patients. Ann Oncol. 2014; 25:1536-43. I Article I PubMed

10. Teschendorff AE, Gomez S, Arenas A, El-Ashry D, Schmidt M, Gehrmann $\mathrm{M}$ and Caldas $\mathrm{C}$. Improved prognostic classification of breast cancer defined by antagonistic activation patterns of immune response pathway modules. BMC Cancer. 2010; 10:604. I Article I PubMed Abstract | PubMed FullText

11. Ohta A, Gorelik E, Prasad SJ, Ronchese F, Lukashev D, Wong MK, Huang X, Caldwell S, Liu K, Smith P, Chen JF, Jackson EK, Apasov S, Abrams S and Sitkovsky M. A2A adenosine receptor protects tumors from antitumor T cells. Proc Natl Acad Sci U S A. 2006; 103:13132-7. I Article I PubMed Abstract | PubMed FullText

12. Zheng X, Koropatnick J, Chen D, Velenosi T, Ling H, Zhang X, Jiang N, Navarro B, Ichim TE, Urquhart B and Min W. Silencing IDO in dendritic cells: a novel approach to enhance cancer immunotherapy in a murine breast cancer model. Int J Cancer. 2013; 132:967-77. | Article | PubMed

13. Silva-Santos B, Serre K and Norell H. gammadelta T cells in cancer. Nat Rev Immunol. 2015; 15:683-91. | Article | PubMed

14. Ma C, Zhang Q, Ye J, Wang F, Zhang Y, Wevers E, Schwartz T, Hunborg $P$, Varvares MA, Hoft DF, Hsueh EC and Peng G. Tumor-infiltrating gammadelta $\mathrm{T}$ lymphocytes predict clinical outcome in human breast cancer. J Immunol. 2012; 189:5029-36. | Article | PubMed Abstract | PubMed FullText

15. Coffelt SB, Kersten K, Doornebal CW, Weiden J, Vrijland K, Hau CS, Verstegen NJ, Ciampricotti M, Hawinkels LJ, Jonkers J and de Visser KE. IL17-producing gammadelta T cells and neutrophils conspire to promote breast cancer metastasis. Nature. 2015; 522:345-8. | Article | PubMed Abstract | PubMed FullText

16. Denkert C, Loibl S, Noske A, Roller M, Muller BM, Komor M, Budczies J, Darb-Esfahani S, Kronenwett R, Hanusch C, von Torne C, Weichert W, Engels K, Solbach C, Schrader I, Dietel M and von Minckwitz G. Tumorassociated lymphocytes as an independent predictor of response to neoadjuvant chemotherapy in breast cancer. J Clin Oncol. 2010; 28:10513. | Article | PubMed

17. Denkert C, von Minckwitz G, Brase JC, Sinn BV, Gade S, Kronenwett R, Pfitzner BM, Salat C, Loi S, Schmitt WD, Schem C, Fisch K, Darb-Esfahani S, Mehta K, Sotiriou C, Wienert S, Klare P, Andre F, Klauschen F, Blohmer JU, Krappmann K, Schmidt M, Tesch H, Kummel S, Sinn P, Jackisch C, Dietel $\mathrm{M}$, Reimer T, Untch $\mathrm{M}$ and Loibl S. Tumor-infiltrating lymphocytes and response to neoadjuvant chemotherapy with or without carboplatin in human epidermal growth factor receptor 2-positive and triple-negative primary breast cancers. J Clin Oncol. 2015; 33:983-91. | Article I PubMed 
Tamkus et al. Oncology Discovery 2016,

18. Sikov WM, Berry DA, Perou CM, Singh B, Cirrincione CT, Tolaney SM, Kuzma CS, Pluard TJ, Somlo G, Port ER, Golshan M, Bellon JR, Collyar D, Hahn OM, Carey LA, Hudis CA and Winer EP. Impact of the addition of carboplatin and/or bevacizumab to neoadjuvant once-per-week paclitaxel followed by dose-dense doxorubicin and cyclophosphamide on pathologic complete response rates in stage II to III triple-negative breast cancer: CALGB 40603 (Alliance). J Clin Oncol. 2015; 33:13-21. | Article | PubMed Abstract | PubMed FullText

19. Dieci MV, Criscitiello C, Goubar A, Viale G, Conte P, Guarneri V, Ficarra G, Mathieu MC, Delaloge S, Curigliano G and Andre F. Prognostic value of tumor-infiltrating lymphocytes on residual disease after primary chemotherapy for triple-negative breast cancer: a retrospective multicenter study. Ann Oncol. 2014; 25:611-8. | Article I PubMed Abstract | PubMed FullText

20. Loi S, Sirtaine N, Piette F, Salgado R, Viale G, Van Eenoo F, Rouas G, Francis P, Crown JP, Hitre E, de Azambuja E, Quinaux E, Di Leo A, Michiels $S$, Piccart MJ and Sotiriou C. Prognostic and predictive value of tumorinfiltrating lymphocytes in a phase III randomized adjuvant breast cancer trial in node-positive breast cancer comparing the addition of docetaxel to doxorubicin with doxorubicin-based chemotherapy: BIG 02-98. J Clin Oncol. 2013; 31:860-7. | Article | PubMed

21. Adams S, Gray RJ, Demaria S, Goldstein L, Perez EA, Shulman LN, Martino S, Wang M, Jones VE, Saphner TJ, Wolff AC, Wood WC, Davidson NE, Sledge GW, Sparano JA and Badve SS. Prognostic value of tumorinfiltrating lymphocytes in triple-negative breast cancers from two phase III randomized adjuvant breast cancer trials: ECOG 2197 and ECOG 1199. J Clin Oncol. 2014; 32:2959-66. | Article | PubMed Abstract I PubMed FullText

22. Loi S, Michiels S, Salgado R, Sirtaine N, Jose V, Fumagalli D, KellokumpuLehtinen PL, Bono P, Kataja V, Desmedt C, Piccart MJ, Loibl S, Denkert $\mathrm{C}$, Smyth MJ, Joensuu $\mathrm{H}$ and Sotiriou $\mathrm{C}$. Tumor infiltrating lymphocytes are prognostic in triple negative breast cancer and predictive for trastuzumab benefit in early breast cancer: results from the FinHER trial. Ann Oncol. 2014; 25:1544-50. I Article I PubMed

23. Zitvogel L, Apetoh L, Ghiringhelli F and Kroemer G. Immunological aspects of cancer chemotherapy. Nat Rev Immunol. 2008; 8:59-73. | Article I PubMed

24. Hato SV, Khong A, de Vries IJ and Lesterhuis WJ. Molecular pathways: the immunogenic effects of platinum-based chemotherapeutics. Clin Cancer Res. 2014; 20:2831-7. | Article | PubMed

25. Perez EA, Ballman KV, Tenner KS, Thompson EA, Badve SS, Bailey $\mathrm{H}$ and Baehner FL. Association of Stromal Tumor-Infiltrating Lymphocytes With Recurrence-Free Survival in the N9831 Adjuvant Trial in Patients With Early-Stage HER2-Positive Breast Cancer. JAMA Oncol. 2016; 2:56-64. I Article I PubMed

26. Salgado R, Denkert C, Campbell C, Savas P, Nuciforo P, Aura C, de Azambuja E, Eidtmann H, Ellis CE, Baselga J, Piccart-Gebhart MJ, Michiels S, Bradbury I, Sotiriou C and Loi S. Tumor-Infiltrating Lymphocytes and Associations With Pathological Complete Response and Event-Free Survival in HER2-Positive Early-Stage Breast Cancer Treated With Lapatinib and Trastuzumab: A Secondary Analysis of the NeoALTTO Trial. JAMA Oncol. 2015; 1:448-54. I Article I PubMed

27. Varadan V, Gilmore H, Miskimen KL, Tuck D, Parsai S, Awadallah A, Krop IE, Winer EP, Bossuyt V, Somlo G, Abu-Khalaf MM, Fenton MA, Sikov W and Harris LN. Immune Signatures Following Single Dose Trastuzumab Predict Pathologic Response to PreoperativeTrastuzumab and Chemotherapy in HER2-Positive Early Breast Cancer. Clin Cancer Res. 2016. | Article | PubMed

28. DeNardo DG, Brennan DJ, Rexhepaj E, Ruffell B, Shiao SL, Madden SF, Gallagher WM, Wadhwani N, Keil SD, Junaid SA, Rugo HS, Hwang ES, Jirstrom K, West BL and Coussens LM. Leukocyte complexity predicts breast cancer survival and functionally regulates response to chemotherapy. Cancer Discov. 2011; 1:54-67. I Article I PubMed Abstract | PubMed FullText

29. Tsutsui S, Yasuda K, Suzuki K, Tahara K, Higashi H and Era S. Macrophage infiltration and its prognostic implications in breast cancer: the relationship with VEGF expression and microvessel density. Oncol Rep. 2005; 14:425-31. | Article | PubMed
30. Hume DA and MacDonald KP. Therapeutic applications of macrophage colony-stimulating factor-1 (CSF-1) and antagonists of CSF-1 receptor (CSF-1R) signaling. Blood. 2012; 119:1810-20. | Article I PubMed

31. Ries CH, Cannarile MA, Hoves S, Benz J, Wartha K, Runza V, Rey-Giraud F, Pradel LP, Feuerhake F, Klaman I, Jones T, Jucknischke U, Scheiblich S, Kaluza K, Gorr IH, Walz A, Abiraj K, Cassier PA, Sica A, Gomez-Roca C, de Visser KE, Italiano A, Le Tourneau C, Delord JP, Levitsky H, Blay JY and Ruttinger D. Targeting tumor-associated macrophages with anti-CSF1R antibody reveals a strategy for cancer therapy. Cancer Cell. 2014; 25:846-59. | Article | PubMed

32. Strachan DC, Ruffell B, Oei Y, Bissell MJ, Coussens LM, Pryer N and Daniel D. CSF1R inhibition delays cervical and mammary tumor growth in murine models by attenuating the turnover of tumorassociated macrophages and enhancing infiltration by CD8 T cells. Oncoimmunology. 2013; 2:e26968. | Article | PubMed Abstract | PubMed FullText

33. Pardoll DM. The blockade of immune checkpoints in cancer immunotherapy. Nat Rev Cancer. 2012; 12:252-64. | Article I PubMed Abstract | PubMed FullText

34. Pauken KE and Wherry EJ. Overcoming T cell exhaustion in infection and cancer. Trends Immunol. 2015; 36:265-76. | Article I PubMed Abstract | PubMed FullText

35. Awad MM and Hammerman PS. Durable Responses With PD-1 Inhibition in Lung and Kidney Cancer and the Ongoing Search for Predictive Biomarkers. J Clin Oncol. 2015; 33:1993-4. I Article I PubMed

36. Postow MA, Callahan MK and Wolchok JD. Immune Checkpoint Blockade in Cancer Therapy. J Clin Oncol. 2015; 33:1974-82. | Article I PubMed

37. Di Giacomo AM, Danielli R, Guidoboni M, Calabro L, Carlucci D, Miracco C, Volterrani L, Mazzei MA, Biagioli M, Altomonte M and Maio M. Therapeutic efficacy of ipilimumab, an anti-CTLA-4 monoclonal antibody, in patients with metastatic melanoma unresponsive to prior systemic treatments: clinical and immunological evidence from three patient cases. Cancer Immunol Immunother. 2009; 58:1297-306. I Article I PubMed

38. Wolchok JD, Hoos A, O'Day S, Weber JS, Hamid O, Lebbe C, Maio M, Binder M, Bohnsack O, Nichol G, Humphrey R and Hodi FS. Guidelines for the evaluation of immune therapy activity in solid tumors: immunerelated response criteria. Clin Cancer Res. 2009; 15:7412-20. | Article | PubMed

39. Emens LA, Braiteh FS, Cassier P, Delord J-P, Eder JP, Fasso M, Xiao Y, Wang $\mathrm{Y}$, Molinero L, Chen DS and Krop I. Inhibition of PD-L1 by MPDL3280A leads to clinical activity in patients with metastatic triple-negative breast cancer. AACR meeting. 2015. | Article

40. Nanda R, Chow LQ, Dees EC, Berger R, Gupta S, Geva R, Pusztai L, DolledFilhart M, Emancipator K, Gonzalez EJ, Houp J, Pathiraja K, Karantza V, lannone R, Gause CK, Cheng JD and Buisseret L. A phase Ib study of pembrolizumab (MK-3475) in patients with advanced triple-negative breast cancer. SABCS meeting. 2014. I Article

41. Dirix LY, Takacs I, Nikolinakos P, Jerusalem G, Arkenau H-T, Hamilton EP, von Heydebreck A, Grote H-J, Chin K and Lippman ME. Avelumab (MSB0010718C), an anti-PD-L1 antibody, in patients with locally advanced or metastatic breast cancer: A phase Ib JAVELIN solid tumor trial. SABCS meeting. 2015.

42. Rugo HS, Delord J-P, Im S-A, Ott PA, Piha-Paul SA, Bedard PL, Sachdev J, Le Tourneau C, van Brummelen E, Varga A, Saraf S, Pietrangelo D, Karantza V and Tan A. Preliminary efficacy and safety of pembrolizumab (MK-3475) in patients with PD-L1-positive, estrogen receptor-positive (ER+)/ HER2-negative advanced breast cancer enrolled in KEYNOTE-028. SABCS meeting. 2015.

43. Chen $G$ and Emens LA. Chemoimmunotherapy: reengineering tumor immunity. Cancer Immunol Immunother. 2013; 62:203-16. | Article | PubMed Abstract | PubMed FullText

44. Pfannenstiel LW, Lam SS, Emens LA, Jaffee EM and Armstrong TD. Paclitaxel enhances early dendritic cell maturation and function through TLR4 signaling in mice. Cell Immunol. 2010; 263:79-87. | Article | PubMed Abstract | PubMed FullText

45. Machiels JP, Reilly RT, Emens LA, Ercolini AM, Lei RY, Weintraub D, Okoye 
Tamkus et al. Oncology Discovery 2016,

Fl and Jaffee EM. Cyclophosphamide, doxorubicin, and paclitaxel enhance the antitumor immune response of granulocyte/macrophagecolony stimulating factor-secreting whole-cell vaccines in HER-2/neu tolerized mice. Cancer Res. 2001; 61:3689-97. | Article | PubMed

46. Bianchini $G$ and Gianni $L$. The immune system and response to HER2targeted treatment in breast cancer. Lancet Oncol. 2014; 15:e58-68. | Article I PubMed

47. Sharabi AB, Nirschl CJ, Kochel CM, Nirschl TR, Francica BJ, Velarde E, Deweese TL and Drake CG. Stereotactic Radiation Therapy Augments Antigen-Specific PD-1-Mediated Antitumor Immune Responses via Cross-Presentation of Tumor Antigen. Cancer Immunol Res. 2015; 3:34555. | Article | PubMed Abstract | PubMed FullText

48. Twyman-Saint Victor C, Rech AJ, Maity A, Rengan R, Pauken KE, Stelekati E, Benci JL, Xu B, Dada H, Odorizzi PM, Herati RS, Mansfield KD, Patsch D, Amaravadi RK, Schuchter LM, Ishwaran H, Mick R, Pryma DA, Xu X, Feldman MD, Gangadhar TC, Hahn SM, Wherry EJ, Vonderheide RH and Minn AJ. Radiation and dual checkpoint blockade activate nonredundant immune mechanisms in cancer. Nature. 2015; 520:373-7. I Article | PubMed Abstract | PubMed FullText

49. Postow MA, Callahan MK, Barker CA, Yamada Y, Yuan J, Kitano S, Mu Z, Rasalan T, Adamow M, Ritter E, Sedrak C, Jungbluth AA, Chua R, Yang AS, Roman RA, Rosner S, Benson B, Allison JP, Lesokhin AM, Gnjatic S and Wolchok JD. Immunologic correlates of the abscopal effect in a patient with melanoma. N Engl J Med. 2012; 366:925-31. | Article | PubMed Abstract | PubMed FullText

50. Wang YS, Yang G, Wang YY, Yang JL and Yang K. Early efficacy of stereotactic body radiation therapy combined with adoptive immunotherapy for advanced malignancies. Mol Clin Oncol. 2013; 1:925-929. | Article | PubMed Abstract | PubMed FullText

51. Dedeurwaerder S, Desmedt C, Calonne E, Singhal SK, Haibe-Kains B, Defrance M, Michiels S, Volkmar M, Deplus R, Luciani J, Lallemand F, Larsimont D, Toussaint J, Haussy S, Rothe F, Rouas G, Metzger O, Majjaj S, Saini K, Putmans P, Hames G, van Baren N, Coulie PG, Piccart M, Sotiriou $C$ and Fuks F. DNA methylation profiling reveals a predominant immune component in breast cancers. EMBO Mol Med. 2011; 3:726-41. | Article | PubMed Abstract | PubMed FullText

52. Yardley DA, Ismail-Khan RR, Melichar B, Lichinitser M, Munster PN, Klein PM, Cruickshank S, Miller KD, Lee MJ and Trepel JB. Randomized phase II, double-blind, placebo-controlled study of exemestane with or without entinostat in postmenopausal women with locally recurrent or metastatic estrogen receptor-positive breast cancer progressing on treatment with a nonsteroidal aromatase inhibitor. J Clin Oncol. 2013; 31:2128-35. | Article | PubMed

53. Bubenik J. Tumour MHC class I downregulation and immunotherapy (Review). Oncol Rep. 2003; 10:2005-8. I Article I PubMed

54. Maio M, Covre A, Fratta E, Di Giacomo AM, Taverna P, Natali PG, Coral $S$ and Sigalotti L. Molecular Pathways: At the Crossroads of Cancer Epigenetics and Immunotherapy. Clin Cancer Res. 2015; 21:4040-7. I Article I PubMed

55. Kim K, Skora AD, Li Z, Liu Q, Tam AJ, Blosser RL, Diaz LA, Jr., Papadopoulos $\mathrm{N}$, Kinzler KW, Vogelstein B and Zhou S. Eradication of metastatic mouse cancers resistant to immune checkpoint blockade by suppression of myeloid-derived cells. Proc Natl Acad Sci U S A. 2014; 111:11774-9. | Article | PubMed Abstract | PubMed FullText

56. Meraviglia S, Eberl M, Vermijlen D, Todaro M, Buccheri S, Cicero G, La Mendola C, Guggino G, D’Asaro M, Orlando V, Scarpa F, Roberts A, Caccamo N, Stassi G, Dieli F and Hayday AC. In vivo manipulation of Vgamma9Vdelta2 $\mathrm{T}$ cells with zoledronate and low-dose interleukin-2 for immunotherapy of advanced breast cancer patients. Clin Exp Immunol. 2010; 161:290-7. | Article | PubMed Abstract | PubMed FullText

57. Noguchi A, Kaneko T, Kamigaki T, Fujimoto K, Ozawa M, Saito M, Ariyoshi $\mathrm{N}$ and Goto S. Zoledronate-activated Vgamma9gammadelta $\mathrm{T}$ cell-based immunotherapy is feasible and restores the impairment of gammadelta T cells in patients with solid tumors. Cytotherapy. 2011; 13:92-7. I Article I PubMed

58. Idrees AS, Sugie T, Inoue C, Murata-Hirai K, Okamura H, Morita CT, Minato N, Toi M and Tanaka Y. Comparison of gammadelta T cell responses and farnesyl diphosphate synthase inhibition in tumor cells pretreated with zoledronic acid. Cancer Sci. 2013; 104:536-42. | Article | PubMed Abstract I PubMed FullText

59. Kunzmann V, Kimmel B, Herrmann T, Einsele $H$ and Wilhelm M. Inhibition of phosphoantigen-mediated gammadelta T-cell proliferation by CD4+ CD25+ FoxP3+ regulatory T cells. Immunology. 2009; 126:256-67. | Article | PubMed Abstract | PubMed FullText

60. Gertner-Dardenne J, Bonnafous C, Bezombes C, Capietto AH, Scaglione V, Ingoure S, Cendron D, Gross E, Lepage JF, Quillet-Mary A, Ysebaert L, Laurent $\mathrm{G}$, Sicard $\mathrm{H}$ and Fournie JJ. Bromohydrin pyrophosphate enhances antibody-dependent cell-mediated cytotoxicity induced by therapeutic antibodies. Blood. 2009; 113:4875-84. | Article | PubMed

61. Tokuyama H, Hagi T, Mattarollo SR, Morley J, Wang Q, So HF, Moriyasu $F$, Nieda $M$ and Nicol AJ. V gamma 9 V delta $2 \mathrm{~T}$ cell cytotoxicity against tumor cells is enhanced by monoclonal antibody drugs--rituximab and trastuzumab. Int J Cancer. 2008; 122:2526-34. | Article | PubMed

62. Capietto $A H$, Martinet $L$ and Fournie JJ. Stimulated gammadelta $T$ cells increase the in vivo efficacy of trastuzumab in HER-2+ breast cancer. $J$ Immunol. 2011; 187:1031-8. | Article | PubMed

63. Lee DW, Gardner R, Porter DL, Louis CU, Ahmed N, Jensen M, Grupp SA and Mackall CL. Current concepts in the diagnosis and management of cytokine release syndrome. Blood. 2014; 124:188-95. | Article | PubMed Abstract | PubMed FullText

64. Lum LG, Thakur A, Al-Kadhimi Z, Colvin GA, Cummings FJ, Legare RD, Dizon DS, Kouttab N, Maizel A, Colaiace W, Liu Q and Rathore R. Targeted T-cell Therapy in Stage IV Breast Cancer: A Phase I Clinical Trial. Clin Cancer Res. 2015; 21:2305-14. | Article | PubMed Abstract | PubMed FullText

65. John LB, Devaud C, Duong CP, Yong CS, Beavis PA, Haynes NM, Chow MT, Smyth MJ, Kershaw MH and Darcy PK. Anti-PD-1 antibody therapy potently enhances the eradication of established tumors by genemodified T cells. Clin Cancer Res. 2013; 19:5636-46. | Article | PubMed

66. Klinger M, Benjamin J, Kischel R, Stienen S and Zugmaier G. Harnessing T cells to fight cancer with BiTE((R)) antibody constructs - past developments and future directions. Immunol Rev. 2016; 270:193-208. I Article I PubMed

67. Taube JM. Unleashing the immune system: PD-1 and PD-Ls in the pretreatment tumor microenvironment and correlation with response to PD-1/PD-L1 blockade. Oncoimmunology. 2014; 3:e963413. | Article | PubMed Abstract | PubMed FullText

68. Rizvi NA, Hellmann MD, Snyder A, Kvistborg P, Makarov V, Havel JJ, Lee W, Yuan J, Wong P, Ho TS, Miller ML, Rekhtman N, Moreira AL, Ibrahim F, Bruggeman C, Gasmi B, Zappasodi R, Maeda Y, Sander C, Garon EB, Merghoub T, Wolchok JD, Schumacher TN and Chan TA. Cancer immunology. Mutational landscape determines sensitivity to PD-1 blockade in non-small cell lung cancer. Science. 2015; 348:124-8. | Article I PubMed

69. Snyder A, Wolchok JD and Chan TA. Genetic basis for clinical response to CTLA-4 blockade. N Engl J Med. 2015; 372:783. | Article | PubMed

70. Le DT, Uram JN, Wang H, Bartlett BR, Kemberling H, Eyring AD, Skora $A D$, Luber BS, Azad NS, Laheru D, Biedrzycki B, Donehower RC, Zaheer A, Fisher GA, Crocenzi TS, Lee JJ, Duffy SM, Goldberg RM, de la Chapelle A, Koshiji M, Bhaijee F, Huebner T, Hruban RH, Wood LD, Cuka N, Pardol DM, Papadopoulos N, Kinzler KW, Zhou S, Cornish TC, Taube JM, Anders RA, Eshleman JR, Vogelstein B and Diaz LA, Jr. PD-1 Blockade in Tumors with Mismatch-Repair Deficiency. N Engl J Med. 2015; 372:2509-20. | Article I PubMed

\section{Citation:}

Tamkus D and Joginpally T. Therapeutic strategies to reverse immunosuppressive breast cancer microenvironment. Oncol Discov. 2016; 4:1. http://dx.doi.org/10.7243/2052-6199-4-1 